\title{
Spell of Demise, Psychosis and Haunting: Gothicism as a Rudimentary Attribute in the Works of Edgar Allen Poe
}

\author{
Mirza Noman Shamas ${ }^{*}$, Sana Akram², Dr. Akbar Khan ${ }^{3}$, Zobia Ehsan ${ }^{4}$, Aqsa Khadim ${ }^{5}$ \\ ${ }^{1-3}$ University of Lahore Gujrat Campus, Department of English Language and Literature \\ ${ }^{4,5}$ Student of M. Phil in English Literature, University of Lahore Gujrat Campus
}

DOI: $10.36348 /$ sijll.2021.v04i04.003

| Received: 16.03.2021 | Accepted: 21.04.2021 | Published: 29.04.2021

*Corresponding author: Mirza Noman Shamas

\section{Abstract}

Edgar Allen Poe is well known writer in the history of literature due to being bestowed with the unique type of stories and novels. Horror, demise, fester, madness, lunacy and awfulness are the most common features of his work. Similarly, Gothicism is an important movement of Sweden that remained active for long duration of time. Furthermore, demise, madness and haunting places are also the major attributes of the Gothicism. Therefore, it can be observed that work of EAP is spell bound by the major features of Gothicism. Various stories and novels including "Ligea", "The Cask of Amontillado", "Tell Tale Heart" and "The Fall of the House of Usher" are the perfect examples for proving the fact that work of EAP embellished with gothic features. However, very literature is available for highlighting this important scenario of literature and needs a detailed analysis for enlightening the spell bound work of EAP by Gothicism. Thus, present research covers these entire research gaps and is a source of opening a window for new researchers to work in the light of above explained theme of work. In the light of results obtained by qualitative analysis, it can be concluded that our hypothesis that work of EAP is spell bound by the Gothicism is quite significantly true supported by the context citation of the above explained short stories and novels.

Keywords: Spell Bound, Gothicism, Edger Allen Poe, Attributes.

Copyright (C) 2021 The Author(s): This is an open-access article distributed under the terms of the Creative Commons Attribution 4.0 International License (CC BY-NC 4.0) which permits unrestricted use, distribution, and reproduction in any medium for non-commercial use provided the original author and source are credited.

\section{INTRODUCTION}

Horror, demise, fester, madness, lunacy and awfulness are the major attributes of Gothicism and these most important features of Edgar Allen Poe's (EAP) novels, stories, fictions and other write-up exertion [1-3]. This is the well-known reason that evens the unknown person who read his work is able to differentiate and easily recognize the work of EAP [46]. The most well-known feature of EAP is "bereavement and fester" that is major attribute of all the stories and novels of EAP and thus, one of the dominant character of his every story pass through the dilemma of death and decay. This dynamic feature spell bound the whole situation of the stories of the EAP and darkness prevails for their loved ones [7, 8]. "Ligea" is well known fictional story of EAP and is the most suitable example of this actuality. In "Ligea" chronicler found himself indulged in the darkness of loneliness after the unacceptable death of his love of life [9- 12]. He tries to compose himself and pass through the dilemma of unbearable loss; however, he found darkness and dreadful surroundings around him. This dominating trait creates a link of Gothicism with EAP's work and then, at the end of the story, he further creates spell of gothic features by introducing the supernatural aspect [13-15].Although death was confirmed in the start for the love of storyteller's life, however, proceeding towards closing stages, she reappears by adopting some sort of mystical supremacy Hunt [16]

In the above mentioned story although the end scenes were quite soothing, however, the sorrow of death remained the dominating factor throughout the context [17- 20].Death of Ligea became the griefstricken dilemma for all the other characters. Reemergence of Ligea along with the sister of Roderick made the involvement of supernatural powers in the story that changed the mind of readers about death and demise [21, 22]. Madness, lunacy and insanity are other rudimentary part of gothic attributes are the important features of EAP's work. Two well-known short stories namely; The Cask of Amontillado along with Tell Tale Heart are the perfect examples of EAP's gothic expression in the form of madness and insanity [23-26]. In both stories the characters show the extreme level of insanity and lunacy. Moreover, in short novel "Ligea" 
Mirza Noman Shamas et al., Sch Int J Linguist Lit, Apr, 2021; 4(4): 100-105

the main character Ligea although is clear depiction of glowing feature of story, however, the author has embellished her with various attributes of insanity et al., [27- 29].

Similarly, Rowena, leading role of "Tell Tale Heart" is a clear prove that all the work of EAP is in spell of Gothicism [30, 31, 32].Her actions, way of talk and behavior with other people explains that Rowena is patient of mental illness, she has n link with actuality and reality, rather remain indulged in her own world of imaginations [33-36]. In addition, "The Fall of the House of Usher" further enlightens the gothic features of work written by EAP and thus, a faultless instance for discussing the strange behavior of Roderick in the story [37-39]. In currently mentioned example, EAP has beautifully explained all the rudimentary features of Gothicism by incorporating the addition of death, demise, madness coupled with ghostly locality of story that increase the interest of reader as well as prevailing the preoccupation of supernatural powers [39-41]. Furthermore, description of ethereal house by saying grey ghostly walls of the house, darkness and obscurity throughout of the house and certain unheard voices increase the extremeness of horror attribute [42-44].

Additionally, in the story of "The Cask of Amontillado" the chronicler demonstrates the extreme level of hate towards "Fortunato" that has been presented as the foe of the earlier one [45, 46]. All the above explained examples are the clear depiction for the confirmation of spell bound nature of the work of the EAP by Gothicism [47-50]. Therefore, gothic features are the preliminary attributes of the EAP's work that differentiate him from all others. Any booklover that starts reading the English literature can easily differentiate the work of EAP just by reading the content due to prevailing spell of Gothicism et al., [5154]. Therefore, it is a proximal approach to provide a detailed analysis for the work of EAP in respect of Gothicism. However, there is very less literature that explains this marvelous aspect of study. Moreover, every researcher tried to give the briefings for only one to two stories for providing the analysis of the novel or stories [55-57]. Contrary to this, our current study is devised to cover all such type of issues and to give the readers a detailed analysis for the work of EAP. Therefore, it can be stated that present study will enlighten all the untold features of all the stories and novels of the EAP.

\section{REVIEW OF LITERATURE}

Edgar Allen Poe is well known novelist along with efficient travel stories. Gothic attributes including revulsion, death, ghostly, demise and decay are the major gems of work of EAP. Very little literature is available that reveals the detailed analysis of EAP's work under the light of Gothicism. Han and Guo [5] have explained the story of "The Fall of the House of Usher" in a beautiful way. The author is of the view that story is under the full of gothic spell. The house mentioned in the story is haunted and it creates horror throughout the story. The walls of the house are of ancient types coupled with dark and grey color that increase the level of dreadfulness. Furthermore, Roderick is character that pass through various stages of demise and decay. Throughout the story Roderick looks like a person that reappears after death to create the situations of horror and ghostly. These are the basic features of Gothicism that are very clear in the story of EAP. First EAP showed the involvement of death and horror in the story and then proceeding towards the ending stages, he added the involvement of supernatural powers by generating a link of Roderick with vampires.

Similarly, Setiawati and Hersulastuti [12] explains the famous story of Edger Allen Poe namely; "Ligea" that is also following the same track of writeup as EAP used for other stories and novel. EAP in his above mentioned story enlighten the worth of love in his story and says that after the ending of our loved ones the beauty of life faints. Author says that EAP has beautifully explained the extreme level of love of narrator for his love of life named 'ligea', however, after her death, he finds darkness everywhere. He doesn't enjoy the life rather count the days of life and sorrows along with disappointments. Therefore, the author concluded that EAP is unique writer whose work is spell bound to the various aspects of gothic attributes.

Whatley [58] enlightened the most dominating feature of Gothicism that is death and demise. "The Assignation" is a famous story of Edgar Allen Poe and in this story death of two important characters happens drastically. "Prince Mentoni" along "Marchesa Aphrodite", the leading characters of the story attempt suicide to get rid of the hard of life at the same duration of time. Furthermore, he involves the level of madness and insanity in the story due to which both accomplish their end to their lives by their own hands. He said that to accept the damage and demise that occur through accidents and other natural disaster are even acceptable and easy to move on for others after that. However, to accept the end to one's life by killing themselves is more than strange to accept and endorse.

Therefore, the above mentioned review of literature is highly supportive to proceed for this type of research. As the above explained authors enlightened the very few stories of Edgar Allen Poe and provided the analysis of his work by keeping in view the rudimentary features of Gothicism. No researcher has used three to four stories for general description and analysis of EAP's work that is highly spell bound by the rudimentary features of gothic attributes. Our present study is a milestone in this regard as in the limelight of above cited review of literature; we have planned to perform the detailed analysis of various stories of EAP with respect to Gothicism. 
Mirza Noman Shamas et al., Sch Int J Linguist Lit, Apr, 2021; 4(4): 100-105

\section{Frame Work}

The planned study is the shadow of rational standpoint of the interpretative school of thought; it is espouse qualitative research technique to regulate the research inquiries. Customarily qualitative researches antedate to put the emphasis on exposure, discernment and indulgent from the viewpoint of their focus and suggests about the utmost effort for creating a clear change in the lives of common people. Merriam, (2009) has explained the qualitative research as; "Qualitative researchers are concerned in analyzing the assembled thoughts of people, along with their thought about the world and their experience while living in that world. Keeping in view the above mentioned definition of qualitative research, we can conclude that qualitative research is best suited to the present study planned to perform. Therefore, to explain the gothic attributes of the EAP's work qualitative research analysis is pretty good to analysis our data and interpret the results.

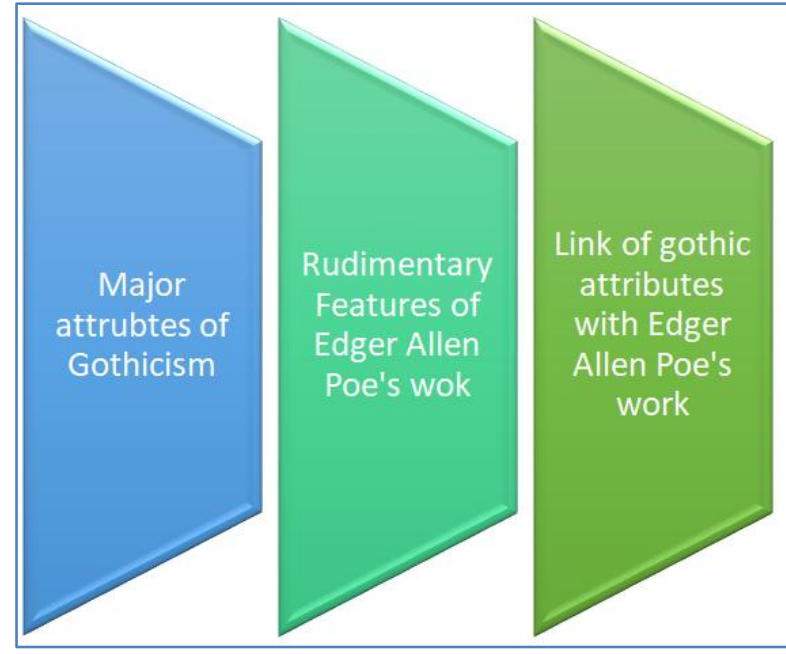

\section{Data Collection}

Data has been collected by using all the possible sources that would be helpful for analyzing the basic theme of our study. For this purpose, two basic categories of data collection have been used namely, primary sources and secondary sources.

\section{Primary Source}

Primary data is comprised of all the original novels of Edger Allen Poe that are being used in our research. Coupled with all the selected novels and short stories of EAP, further data collection was performed by visiting various libraries throughout in the Punjab.

\section{Secondary Source}

Secondary data was collected from various libraries and publications (articles, newspapers and conference proceedings) showing the clear relationship with our context. Little research is done on explaining the gothic attributes of EAP's work. Therefore, all the note-books, articles, magazines and conference proceeding showing the basis for our study were used to properly depicting our results of study.

\section{RESEARCH OBJECTIVES}

Gothicism is an important aspect that covers the madness, death, demise, insanity, disgust and haunted situations. Edgar Allen Poe is well known writer who has revolutionized the English Literature by introducing the various attributes of Gothicism. His work is great reflection of gothic attributes throughout of his stories and novels. However, very little knowledge is available on the analysis of these attributes of EAP's work and no one has put the spotlight to highlight the various short stories and novels of EAP for explaining the gothic features including demise, death, disgust, horror and insanity. Therefore, our present study covers all these knowledge gaps and enlightens the spell bound nature of EAP's work by Gothicism with the following clear objectives in our minds:

- To identify the basic attributes of Gothicism

- To investigate why work of Edgar Allen Poe is spell bound by Gothicism

- To analyze the stories and novels of EAP those are comprised of gothic attributes

- To describe the rudimentary features of work of EAP that makes it gothic

\section{RESEARCH QUESTIONS}

- What are the important characteristics of EAP's work?

- What are the basic attributes of Gothicism?

- Why work of Edgar Allen Poe is spell bound by Gothicism?

- Which stories and novels of EAP are comprised of gothic attributes?

- Which are the rudimentary features of work of EAP that make it gothic?

\section{ANALYSIS AND DISCUSSION}

By using the qualitative technique of data analysis we can analyze our data in the light of context citation and detailed discussion on that reference. Edgar Allen Poe is well known author in the history of English Literature and has provided us with various top ranked stories and novels that have clear link with various attributes of the Gothicism. The most important aspect of Gothicism is death and demise that is distinctive feature of EAP. In his story of "The Fall of the House of Usher" the EAP explains the phenomenon of death and sorrows related to it.

"I have said that the sole effect of my somewhat childish experiment - that of looking down the tarn-had been to deepen the first singular impression. There can be no doubt that the consciousness of the rapid increase of my superstition - for why should I not so term it? - served mainly to accelerate the increase itself. Such, I have long known, is the paradoxical law of all sentiments having terror as a basis. And it might have been for this reason only, that, when I again uplifted my eyes to the 
Mirza Noman Shamas et al., Sch Int J Linguist Lit, Apr, 2021; 4(4): 100-105

house itself, from its image in the pool, there grew in my mind a strange fancy - a fancy so ridiculous, indeed, that I but mention it to show the vivid force of the sensations which oppressed me. I had so worked upon my imagination as really to believe that about the whole mansion and domain there hung an atmosphere which had no affinity with the air of heaven, but which had reeked up from the decayed trees, and the gray wall, and the silent tarn - a pestilent and mystic vapour, dull, sluggish, faintly discernible, and leaden-hued". (Text citation from "The Fall of the House of Usher" by EAP)

The above mentioned context citation clearly indicates that first EAP creates the spell of horror and haunt. The description of house is totally ghostly, old designed walls; grey color and downfall structure are basic features of the concerned residence. Furthermore, crumble form of tress and other plants make the direct relation of story with the gothic features. Similarly, proceeding towards the other attributes of the Gothicism, the main character of the story also known as "Roderick" pretends to remain under the force of supernatural powers. Throughout the story it becomes harder to identify whether the leading character of the story is human being or any other creature from some other world. In addition, his description makes him the person that is bestowed with some ghostlike clout. Therefore, the above mentioned text citation is highly supportive for our title of the article that work of EAP is spell bound by the various attributes of Gothicism. Similarly, other stories of the EAP are also comprised of various features of Gothicism movement and make the work of EAP identifiable even from the first reading.

"There came suddenly to my nostrils the strong peculiar odor of moist earth. . . . I was not within the vault. I had fallen into a trance while absent from home - while among strangers - when, or how, I could not remember - and it was they who had buried me as a dog — nailed up in some coffin — and thrust, deep, deep, and forever, into some ordinary and nameless grave." (Text citation from 'The Premature Burial' by EAP).

The above mentioned paragraph is taken from the story of EAP named, 'The Premature Burial". Death is the most fundamental content of the gothic attributes. Death, demise, decay and perish condition of the things and human beings make the Gothicism an unachievable and annoying movement for the normal mankind. The above mentioned paragraph reveals the most precarious factor of gothic attributes. The narrator feels himself dead and buried beneath the thousand layers of the soil after being indulged and locked in some decayed coffin. Furthermore, the chronicler explains the level of his pains by saying that he don't know wherever he is obscured, the only thing with which he is aware is the tons of soil above him and he is lying in the grave that is unknown to all others. There is no name and identity that is given to him and thus, he resembles himself with some dog that may die accidently and people throw him somewhere to avoid his decayed body and unbearable smell of dead body of the dog. Thus, the above explained paragraph enlighten the fact that EAP is highly impress by the Gothicism movement and consequently, all of his stories and novels are spell bound by the rudimentary features of Gothicism.

"The intellectual faculties appear to have sustained little or no injury, while the disorder is manifested principally or alone, in the state of the feelings, temper, or habits. In cases of this description the moral and active principles of the mind are strangely perverted and depraved; the power of selfgovernment is lost or greatly impaired; and the individual is found to be incapable, not of talking or reasoning upon any subject proposed to him, for this he will often do with great shrewdness and volubility, but of conducting himself with decency and propriety. . . . His wishes and inclinations, his attachments, his likings and disliking have all undergone a morbid change, and this change appears to be the originating cause, or to lie at the foundations of any disturbance which the understanding itself may seem to have sustained, and even in some instances to form throughout the sole manifestation of the disease". (Text citation from "Tell Tale Heart" by EAP)

The above explained paragraph has been taken from "Tell Tale Heart" and it enlightens the most dominating feature of the Gothicism in the terms of madness and/ or insanity. The narrator pas through various stages of life and then feels him abnormal in almost all aspects of life. He undergo through various mental as well as physical disruption and decay. The chronicler reveals that his temper to bear the things has changed a lot and it has become difficult for him to control his anger and other feelings that make him mad and insane. Furthermore, it has become difficult for the narrator to perform his daily routine wise tasks with ease and courage. He remain indulged in sorrows, over thinking and other such type of insanity features that confirm that he is not fine rather suffering from various mental disruptions. Therefore, from the above mentioned examples it can be concluded that work of EAP is highly impressed and spell bound by the gothic features. All the major attributes of Gothicism are the rudimentary components of the work of the EAP. His stories, novels and other write up shows the clear prevailing features of demise, death, horror, insanity, ghostly and perishing components throughout the story and this character makes the work of EAP recognizable from the very first glance.

\section{CONCLUSION}

Conclusion of every study is the most vital component of every research. Significance of every research multiplies up-to great extend with proper conclusion. Thus, in the light of above explained facts it 
Mirza Noman Shamas et al., Sch Int J Linguist Lit, Apr, 2021; 4(4): 100-105

can be concluded that our research is highly significant for supporting the hypothesis that work of Edger Allen Poe is spell bound by various attributes of Gothicism. Various short stories and novels namely; "Ligea", "The Cask of Amontillado", "Tell Tale Heart" and "The Fall of the House of Usher" are the perfect examples for proving the fact that work of EAP embellished with gothic features.

\section{REFERENCES}

1. Fischer, R. K. (2019). The Alert Collector: The Gothic Aesthetic: From the Ancient Germanic Tribes to the Contemporary Goth Subculture.

2. Poe, E. A., \& Williams, G. S. (2019). Reading the Transatlantic Gothic Fiction of Walter Scott and.

3. Rajguru, S.P. (2020). Gothic Architectural Influences on English Literature. Our Heritage, 68(30), 329-336.

4. Wehmeyer, A. (2019, January). Mimetic creativity in Japanese translations of Edgar Allen Poe. In Japan Forum (Vol. 31, No. 1, pp. 33-63). Routledge.

5. Han, B., \& Guo, M. (2020). Gothic Writing Technique and Yin-Yang Theory in the fall of the House of Usher. Journal of Language Teaching and Research, 11(2), 288-292.

6. Mills, K. A. (2020). Hellish Horses and Monstrous Men: Gothic Horsemanship in Washington Irving and Edgar Allan Poe. In Gothic Animals (pp. 223240). Palgrave Macmillan, Cham.

7. Kennedy, J. G., \& Peeples, S. (Eds.). (2019). the Oxford Handbook of Edgar Allen Poe. Oxford University Press, USA.

8. Poe, E. A., \& Williams, G. S. (2019). Reading the Transatlantic Gothic Fiction of Walter Scott and.

9. Pritchard, H. (2003). Poe's the Tell-Tale Heart. The Explicator, 61(3), 144-147.

10. Rizvi, S. (2019). Erudition and Sickness in Edgar Allan Poe's Gothic Stories. IUSB Graduate Research Journal, 6, 15-26.

11. Jones, D. (2018). T HE fiction. HORROR With STORY it IS characteristic one of the enduring reliance on genres the of unity short of time and effect, and on the creation of an unsettling mood or atmosphere leading to a shocking denouement, horror has proved particularly amenable to the short form, deliberately designed to be consumed in one sitting for maximum impact. A number of the greatest horror writers-Edgar Allan Poe. Edinburgh Companion to the Short Story in English

12. Setiawati, E. E. D., \& Hersulastuti, H. (2019). THE IMAGE OF HORROR AS VIEWED IN EDGAR ALLAN POE'S THREE SHORT STORIES (LIGEA, THE BLACK CAT, THE FALL OF USERS). Lire Journal (Journal of Linguistics and Literature), 3(1), 86-90.

13. Ehrlich, H. (2004). Poe's Seductive Influence on Great Writers.
14. Corben, R. (2014). Edgar Allan Poe's Spirits of the Dead (No. 1-2). Dark Horse Comics.

15. Gabriel, M. A. R. (2019). Edgar Allan Poe: A Source for Miriam Allen Deford. Aletria: Revista de Estudos de Literatura, 29(2), 79-99.

16. Hunt, G. (2019). The Lovecraftian Poe: Essays on Influence, Reception, Interpretation and Transformation. Edited by Sean Moreland.

17. Engel, L. W. (1982). Obsession, Madness, and Enclosure in Poe's" Ligeia" and" Morella". College Literature, 9(2), 140-146.

18. Rollason, C. (1988). The Detective Myth in Edgar Allan Poe's Dupin Trilogy. In American Crime Fiction (pp. 4-22). Palgrave Macmillan, London.

19. Nadal, M. (2016). Trauma and the Uncanny in Edgar Allan Poe's "Ligeia" and "The Fall of the House of Usher". The Edgar Allan Poe Review, 17(2), 178-192.

20. Hladká, A. (2019). Mental Illness In The Works Of Edgar Allan Poe.

21. Chu, T. Y., \& Chu, J. (2018). Influence of Blair on Poe's Gothicism: The Style of Terror and Horror in Poe's Early Woman-Centered Tales. The Edgar Allan Poe Review, 19(2), 177-191.

22. Gale, C. (2018). A Study Guide for Edgar Allan Poe's" Ligeia". Gale, Cengage Learning.

23. Gale, C. (2016). A Study Guide for Edgar Allan Poe's" Ligeia". Gale, Cengage Learning.

24. Guttzeit, G. (2018, July). Authoring Monsters: Mary Shelley, Edgar Allan Poe and Early Nineteenth-Century Figures of Gothic Authorship. In Forum for Modern Language Studies (Vol. 54, No. 3, pp. 279-292). Oxford University Press.

25. George, K. (2019). The Eldritch Storyteller: Revisiting Edgar Allan Poe's inimitable oeuvre. International Journal of English Literature and Social Sciences (IJELS), 4(6).

26. Tomc, S. (2019). Edgar Allan Poe and His Enemies. In The Oxford Handbook of Edgar Allan Poe.

27. Spears, S. (2016). A Place for Poe: The Foreign in Two Tales of the Gothic.

28. Poe, E. A., Shelley, M., Walpole, H., Beckford, W. T., Parsons, E., Godwin, W., \& Allen, G. (2018). 60 GOTHIC CLASSICS-Boxed Set: Dark Fantasy Novels, Supernatural Mysteries, Horror Tales \& Gothic Romances: Frankenstein, The Castle of Otranto, St. Irvyne, The Tell-Tale Heart, The Phantom Ship, The Birth Mark, The Headless Horseman, The Man-Wolf, The Beetle, The Phantom of the Opera... e-artnow.

29. Poe, E. A., Shelley, M., Walpole, H., Beckford, W. T., Parsons, E., Godwin, W., ... \& Peacock, T. L. (2018b). The Greatest Gothic Classics: Frankenstein, The Castle of Otranto, St. Irvyne, The Tell-Tale Heart, The Phantom Ship, The Birth Mark, The Headless Horseman, The Man-Wolf, The Beetle, The Phantom of the Opera... e-artnow.

30. Clarke, F. (2016). Gothic vibrations and Edgar Allan Poe. Horror Studies, 7(2), 205-217. 
Mirza Noman Shamas et al., Sch Int J Linguist Lit, Apr, 2021; 4(4): 100-105

31. Beauchamp, A. (2018). "The Tell-Tale Heart": A Reflection of the Insanity Defense.

32. Yusuf, A. (2018). Gothic Elements and Psychoanalytic Study in the Tell-Tale Heart by Edgar Allan Poe. EDUCULTURAL: International Journal of Education, Culture and Humanities, 1(1), 13-19.

33. Jones, T. (2017). Affairs of the Tell-Tale Heart. Journal of New Zealand Literature (JNZL), (35: 2), 15-31.

34. Ahmed, M. B. (2018). An exploration of Dark Romanticism in Poe's Gothic Fiction: a journey into the conscious and subconscious mind (Doctoral dissertation, BRAC University).

35. Koçsoy, F. G. (2018). THE TRANSGRESSIVE SUBLIME IN EDGAR ALLAN POE'S" THE TELL-TALE HEART" AND" THE IMP OF THE PERVERSE". Journal of International Social Research, 11(58).

36. Jordan, S. (2019). Making Manhattan: Urban hieroglyphics, patternings and tattoos in Edgar Allan Poe's 'The tell-tale heart'and Herman Melville's Moby-Dick; Or, the whale. In Tattoos in crime and detective narratives. Manchester University Press.

37. Walsbergerová, T. (2019). "Making a Mockery of Horror": the double-crossing paranoia of EA Poe's The Tell-Tale Heart and The Black Cat.

38. García, I. M. (2020). Transcolonial Gothic and Decolonial Satire in Ramón Emeterio Betances. The Oxford Handbook of Latino Studies, 412.

39. O'Donnell, K. A. (2019). Translations of Ossian, Thomas Moore and the Gothic by 19th Century European Radical Intellectuals: The Democratic Eastern Federation. Lublin Studies in Modern Languages and Literature, 43(4), 89-104.

40. Buckley, G. R. (2017). Edgar Allan Poe's," The Fall of the House of Usher": a Symbol of the Crumbling Borders of American and Psychic Consciousness and the Birth of Gothic Transcendence. Journal of English Language and Literature, 8(3), 654-658.

41. Gomber, K. (2020). Edgar Allan Poe-Master of 'Monochrome Melancholia. Studies in Indian Place Names, 40(3), 3245-3251.

42. Han, B., \& Guo, M. (2020). Gothic Writing Technique and Yin-Yang Theory in the Fall of the House of Usher. Journal of Language Teaching and Research, 11(2), 288-292.

43. Weisheng, T. (2018). Edgar Allan Poe's Gothic Aesthetics of Things: Rereading "The Fall of the House of Usher". Style, 52(3), 287-301.

44. Schoonover, N. R., \& Falter, M. M. (2020). Exploring vice Characters, Gothic Literature, and the Immigrant Experience in Anya's Ghost. Breaking the Taboo with Young Adult Literature, 153

45. Undalik,. Rajguru, M. S. P., \& Kolekar, T. N. (2020). GOTHIC ARCHITECTURAL INFLENCES ON ENGLISH LITERATURE. Our Heritage, 68(11), 312-316.

46. Wright, T. F. (2016). Edgar Allan Poe and the Southern Gothic. In The Palgrave Handbook of the Southern Gothic (pp. 9-20). Palgrave Macmillan, London.

47. Rizvi, S. (2019). Erudition and Sickness in Edgar Allan Poe's Gothic Stories. IUSB Graduate Research Journal, 6, 15-26.

48. Sugden, E. (2016). The Globalisation of the Gothic South. In The Palgrave Handbook of the Southern Gothic (pp. 69-79). Palgrave Macmillan, London.

49. Bulu, M. (2018). Conflict Analysis of the Main Characters in Short Stories by Edgar Allan Poe. PIONEER: Journal of Language and Literature, 10(1), 1-12.

50. Lopes, E. (2018). Edgar Allan Poe's Gothic Revisited in André Øvredal's The Autopsy of Jane Doe (2016). In 39th Conference of the Portuguese Association for Anglo-American Studies.

51. Shaikh, A., \& Sadenwasser, T. (2020). Portrayal of Mental Illness in Edgar Allan Poe's.

52. Mehta, J. A Comparative Psychological Exploration of Select Short Stories By Edgar Allan Poe Anton Chekhov And Dr Jayant Khatri.

53. Ahmadi, N., Ramadhanti, A., \& Muhaimi, L. Symbol in Edgar Allan Poe's Selected Short Stories and Their Pedagogical Implication: a Semiotic Perspective. Jurnal Ilmiah Profesi Pendidikan, 4(2), 91-93.

54. Song, C. (2019). J. A Psychoanalytic Reading of Edgar Allan Poe's" The Murders in the Rue Morgue". In 4th International Conference on Contemporary Education, Social Sciences and Humanities (ICCESSH 2019). Atlantis Press.

55. Gallo, C. J. (2019). Seeing the 'excessively obvious': The penny press, gender and work in Edgar Allan Poe's Dupin stories. Explorations in Media Ecology, 18(4), 413-434.

56. Alsahafi, M. (2020). A Narrative Discourse Analysis of Poe's Short Story" The Tell-Tale Heart": Implications for Language Teaching. English Language Teaching, 13(1), 1-17.

57. Dean, H. J., \& Boyd, R. L. (2020). Deep into that darkness peering: a computational analysis of the role of depression in Edgar Allan Poe's life and death. Journal of affective disorders, 266, 482-491.

58. Whatley, J. (2020). Gothic Ghosts and Gothic Mirrors. A Companion to World Literature, 1-12. 